\title{
Eksistensi Hak Tanggungan dalam Kontrak Investasi Kolektif Efek Beragun Aset (KIK-EBA) sebagai Konsep Trusts
}

\author{
Riky Rustam \\ Fakultas Hukum Universitas Islam Indonesia \\ Jln. Tamansiswa No. 158 Yogyakarta \\ rikyrustam@yahoo.com
}

\begin{abstract}
This research aims at discussing the problems concerning KIK-EBA agreement related to the existence of personality principles and ownership status of mortgage whose trust is secured in KIK-EBA. The problem discussed is related to any legal effects of the implementation of KIK-EBA as an agreement consisting of three parties on the existence of personality principles and related to the ownership status of mortgage in the securitization mechanism used in KIK-EBA. This was a normative research whose data were collected by using a library research method. The findings conclude that KIK-EBA is not an exception of personality principle; besides, since the formal condition of agreement is not fulfilled, KIK$E B A$ is null and void. The ownership of mortgage in KIK-EBA is still owned by the original creditor although purchase and sale of trust has occurred as a true sale in KIK-EBA.
\end{abstract}

Key words : Collective investment contract, trusts, mortgage

\begin{abstract}
Abstrak
Penelitian ini bertujuan untuk mengemukakan permasalahan mengenai perjanjian KIK-EBA terkait adanya asas personalitas dan status kepemilikan hak tanggungan yang piutangnya disekuritisasi dalam KIK-EBA. Masalah yang diteliti adalah mengenai akibat hukum penerapan KIK-EBA sebagai suatu perjanjian yang terdiri dari tiga pihak terhadap adanya asas personalitas dan mengenai status kepemilikan hak tanggungan dalam mekanisme sekuritisasi yang digunakan dalam KIK-EBA. Metode yang dipakai dalam penelitian ini adalah penelitian normatif dengan mengumpulkan data secara studi pustaka (library research). Hasil penelitian menyimpulkan bahwa KIK-EBA bukanlah salah satu pengecualian dari asas personalitas, selain itu, dengan tidak terpenuhinya syarat formal perjanjian, KIKEBA menjadi batal demi hukum. Kepemilikan hak tanggungan dalam KIK-EBA tetap dimiliki oleh kreditor asal, meskipun telah terjadi jual beli piutang secara jual putus dalam KIK-EBA.
\end{abstract}

Kata kunci : Kontrak investasi kolektif, trusts, hak tanggungan 


\section{Pendahuluan}

Kontrak Investasi Kolektif Efek Beragun Aset (KIK EBA) merupakan suatu bentuk perjanjian yang penerapannya mencontoh konsep trusts dalam sistem hukum common law dan kemudian diterapkan di Indonesia yang menggunakan sistem hukum civil law. ${ }^{1}$ Adanya perbedaan antara sistem hukum common law dan sistem hukum civil law tersebut memiliki dampak terhadap pemberlakukan KIK-EBA di Indonesia yang menimbulkan konflik antara norma yang satu dengan norma yang lainnya.

Konflik norma ini terjadi dikarenakan sebagai salah satu bagian dari kegiatan pasar modal, pelaksanaan KIK-EBA hingga saat ini belum memiliki ketentuan peraturan perundang-undangan khusus (lex specialis) yang mengatur dan melindungi pemberlakuan KIK-EBA di pasar modal Indonesia. ${ }^{2}$

Tidak adanya ketentuan khusus tersebut disebabkan Undang-Undang Pasar Modal Indonesia yaitu Undang-Undang No. 8 Tahun 1995 tentang Pasar Modal (UUPM), hanya mengatur mengenai masalah kontrak investasi kolektif (KIK) (Pasal 18 ayat (1) huruf b), sedangkan mengenai KIK-EBA sama sekali belum diatur dalam undang-undang ini.

Pengaturan mengenai KIK-EBA saat ini hanya dapat ditemukan dalam Peraturan Otoritas Jasa Keuangan (OJK) dan Peraturan BAPEPAM yang salah satunya adalah Keputusan Ketua Badan Pengawas Pasar Modal Nomor Kep493/BL/2008 tentang Perubahan Peraturan Nomor IX.K.1 tentang Pedoman Kontrak Investasi Kolektif Efek Beragun Aset (Peraturan BAPEPAM Nomor IX.K.1). ${ }^{3}$ Tidak adanya peraturan perundang-undangan yang secara khusus mengatur KIK-EBA mengakibatkan belum ada dasar hukum yang kuat untuk dapat melindungi penerapan KIK-EBA dalam pasar modal Indonesia terutama terhadap pertentangan antara konsep KIK-EBA dengan peraturan perundangundangan yang berlaku dan bersifat pemaksa (dwingend recht).

${ }^{1}$ Gunawan Widjaja, "Sekuritisasi Aset dalam Kegiatan Pasar Modal dan Dampak Kasus Subprime Mortgage di Amerika Serikat terhadap Pasar Sekuritas Global”, Jurnal Hukum Bisnis, Volume 27-No.03, 2008, hlm. 53.

${ }^{2}$ Baca Pasal 56 sampai dengan Pasal 63 UUPM.

${ }^{3}$ Hingga penelitian ini dibuat, belum ada ketentuan atau peraturan dari Otoritas Jasa Keuangan yang mengatur tentang KIK-EBA sebagai pengganti ketentuan BAPEPAM tersebut, sehingga berdasarkan Pasal 70 Undang-Undang Nomor 21 Tahun 2011 tentang Otoritas Jasa Keuangan, Peneliti masih menggunakan Peraturan BAPEPAM tersebut sebagai Bahan Penelitian. 
Pertentangan tersebut antara lain: Pertama, pertentangan dengan UndangUndang Nomor 4 Tahun 1996 tentang Hak Tanggungan Atas Tanah Beserta BendaBenda yang Berkaitan dengan Tanah (UUHT). Pertentangan ini terjadi disebabkan Pasal 2 Peraturan BAPEPAM Nomor IX.K.1 menyebutkan bahwa "Aset yang membentuk portofolio kontrak investasi kolektif efek beragun aset dapat diperoleh dari kreditor awal melalui pembelian atau tukar-menukar dengan kontrak investasi kolektif efek beragun aset".

Berdasarkan sistem hukum yang berlaku di Indonesia, pembelian aset yang membentuk portofolio KIK-EBA (dalam hal ini piutang) yang disebutkan Pasal 2 Peraturan BAPEPAM Nomor IX.K.1 tersebut di atas, memiliki implikasi lain yang ditentukan oleh Pasal 16 UUHT, implikasinya adalah adanya ketentuan Pasal 16 ayat (2) UUHT yang menentukan bahwa setiap terjadinya peralihan piutang termasuk dengan mekanisme jual beli, maka hak tanggungan yang melekat pada piutang tersebut juga ikut beralih, dan peralihan hak tanggungan itu wajib untuk didaftarkan. Sebagaimana Pasal 16 ayat (1) UUHT yang menyebutkan "Jika piutang yang dijamin dengan hak tanggungan beralih karena cessie, subrogasi, pewarisan, atau sebab-sebab lain, hak tanggungan tersebut ikut beralih karena hukum kepada kreditor yang baru". Pasal 16 ayat (2) menyebutkan bahwa "beralihnya hak tanggungan sebagaimana dimaksud pada ayat (1) wajib didaftarkan oleh kreditor yang baru kepada kantor pertanahan".

Dalam praktiknya, ketentuan yang diatur dalam Peraturan BAPEPAM Nomor IX.K.1 mengalami pertentangan dengan Pasal 16 ayat (2) UUHT ketika peralihan piutang itu tidak disertai dengan proses pendaftaran karena Peraturan BAPEPAM ini tidak dilengkapi dengan ketentuan yang sama untuk mendaftarkan peralihan piutang.

Pertentangan antara Peraturan BAPEPAM dengan UUHT tersebut jika diselesaikan menggunakan asas lex specialis derogat legi generalis (peraturan yang bersifat khusus dapat mengesampingkan peraturan yang bersifat umum) maupun menggunakan asas lex posterior derogat legi priori (peraturan yang terbaru (posterior) dapat mengesampingkan peraturan yang lama (prior), maka akan tetap memenangkan UUHT dibandingkan Peraturan BAPEPAM karena Peraturan BAPEPAM bukan merupakan bagian dari hierarki peraturan perundang-undangan sebagaimana yang ditentukan oleh Undang-Undang Nomor 12 Tahun 2011 tentang 
Pembentukan Peraturan Perundang-Undangan, Peraturan BAPEPAM tentang KIKEBA ini juga tidak didukung oleh UUPM sebagai Undang-Undang khusus yang mengatur tentang Pasar Modal karena UUPM tersebut hanya mengatur tentang KIK dan tidak mengatur tentang KIK-EBA.

Kedua, KIK-EBA sebagai suatu perjanjian tetapi tidak memenuhi syarat sahnya perjanjian yang ditentukan Kitab Undang-Undang Hukum Perdata Indonesia (KUHPerdata). Keabsahan suatu perjanjian dalam hukum perdata Indonesia ditentukan dengan terpenuhinya syarat sah perjanjian ${ }^{4}$ dan asas-asas pembuatan suatu perjanjian. Jika dilihat dari sistem hukum Indonesia yang menganut sistem hukum civil law, dalam pembuatan suatu perjanjian dikenal adanya asas personalitas yang diatur Pasal 1315 KUHPerdata. Asas ini menentukan bahwa "pada umumnya tak seorang pun dapat mengikatkan diri atas nama sendiri atau meminta ditetapkanya suatu janji selain untuk dirinya sendiri". Dari rumusan ini dapat dipahami bahwa pada dasarnya suatu perjanjian yang dibuat seseorang dalam kapasitasnya sebagai individu atau subjek hukum pribadi, hanya akan berlaku dan mengikat untuk dirinya sendiri. ${ }^{5}$

Pasal 1 ayat (2) Peraturan Otoritas Jasa Keuangan Nomor 15/POJK.04/2014 tentang Laporan Bulanan Kontrak Investasi Kolektif Efek Beragun Aset menyebutkan bahwa:

"Kontrak Investasi Kolektif Efek Beragun Aset (KIK-EBA) adalah kontrak antara manajer investasi dan bank kustodian yang mengikat pemegang efek beragun aset dimana manajer investasi diberi wewenang untuk mengelola portofolio investasi kolektif dan bank kustodian diberi wewenang untuk melaksanakan penitipan kolektif".

Pasal 1 ayat (2) Peraturan OJK tersebut di atas menunjukkan bahwa KIK-EBA adalah kontrak yang tidak hanya mengikat manajer investasi dan bank kustodian selaku pembuat perjanjian namun juga mengikat pihak ketiga yaitu investor, bahkan kedudukan investor dalam perjanjian ini bukan hanya sebagai penerima hak, tetapi juga sebagai pihak yang memiliki kewajiban yaitu kewajiban untuk membayar unit penyertaan yang dikeluarkan manajer investasi. Kewajiban yang dibebankan kepada

${ }^{4}$ Pasal 1320 KUHPerdata.

${ }^{5}$ Kartini Muljadi dan Gunawan Widjaja, Perikatan Yang Labir dari Perjanjian, PT Rajagrafindo Persada, Jakarta, 2003, hlm.14-15. 
investor ini tidak sesuai dengan prinsip yang terkandung dalam perjanjian derden beding (bentuk perjanjian mengikat pihak ketiga sebagai pengecualian asas personalitas yang dikenal dalam sistem hukum civil law seperti di Indonesia), pihak ketiga dalam perjanjian semacam ini hanya merupakan pihak yang menikmati manfaat atas perjanjian tersebut tanpa dibebani suatu kewajiban, ${ }^{6}$ sebagai contoh adalah perjanjian asuransi.

Konstruksi hubungan hukum KIK-EBA yang memiliki tiga pihak ${ }^{7}$ sekaligus di dalamnya tersebut mengakibatkan terjadinya dualisme kepemilikan piutang yang dilekati hak tanggungan yaitu antara legal owner (manajer investasi) dan beneficiary owner (para investor). ${ }^{8}$ Dualisme kepemilikan ini menyebabkan tidak dapat dipahami siapakah yang akan menjadi pemilik hak tanggungan dalam konstruksi KIK-EBA, sebagai pihak yang dapat melakukan pengambilalihan aset apabila debitor cidera janji (wanprestasi).

Selain itu, pertentangan antara peraturan BAPEPAM dan UUHT tersebut di atas juga menyebabkan terlanggarnya ketentuan Pasal 1337 KUHPerdata yang menentukan bahwa "Suatu sebab adalah terlarang, apabila dilarang oleh undangundang, atau apabila berlawanan dengan kesusilaan baik atau ketertiban umum". Hal ini dikarenakan dengan tidak dilakukannya pendaftaran atas peralihan hak tanggungan dalam KIK-EBA, pelaksanaan KIK-EBA tersebut telah melanggar Pasal 16 ayat (2) UUHT yang merupakan syarat formal dari perjanjian formil KIKEBA. ${ }^{9}$

Dari hal-hal di atas dapat dilihat bahwa jenis perjanjian ini adalah perjanjian baru yang baru dikenal dalam sistem hukum civil law sehingga perlu dikaji apakah akibat hukum penerapan konsep KIK-EBA ini dalam sistem hukum Indonesia yang menganut asas personalitas, terutama mengenai masalah kepemilikan hak tanggungan atas benda yang memiliki pengaturan tersendiri dalam hukum Indonesia.

๑. Satrio, Hukum Perjanjian (Perjanjian Pada Umumnya), PT Citra Aditya Bakti, Bandung, 1992, hlm. 82.

${ }^{7}$ Baca juga Pasal 56 ayat (3) Undang-Undang Nomor 8 Tahun 1995 tentang Pasar Modal.

${ }^{8}$ Jono, "Tinjauan Yuridis Reksa Dana yang Berbentuk Kontrak Investasi Kolektif sebagai Bentuk Trusts", Jurnal Hukum Bisnis, volume 25-No. 01, (2006), hlm. 54.

9Subekti, Hukum Perjanjian, Ctk. Kesembilanbelas, PT. Intermasa, Jakarta, 2002, hlm. 25. 


\section{Rumusan Masalah}

Berdasarkan pada latar belakang tersebut di atas, maka rumusan masalah dalam penelitian ini adalah sebagai berikut: pertama, bagaimanakah akibat hukum penerapan KIK-EBA jika ditinjau berdasarkan asas personalitas yang dianut Indonesia? Kedua, bagaimanakah status kepemilikan hak tanggungan atas kredit pemilikan rumah yang piutangnya dialihkan dengan cara sekuritisasi aset tersebut?

\section{Tujuan Penelitian}

Penelitian ini bertujuan untuk, pertama, menjelaskan akibat hukum penerapan KIK-EBA ini jika ditinjau berdasarkan asas personalitas yang dianut Indonesia. Kedua, menguraikan status kepemilikan hak tanggungan atas kredit pemilikan rumah yang piutangnya dialihkan dengan cara sekuritisasi aset ditinjau dari segi hukum Indonesia.

\section{Metode Penelitian}

Penelitian ini adalah penelitian hukum normatif atau penelitian hukum kepustakaan yang mengumpulkan data secara studi kepustakaan (library research). Data yang digunakan adalah data sekunder yang terdiri dari bahan hukum primer dan bahan hukum sekunder. Semua bahan hukum yang telah dikumpulkan tersebut akan dianalisis secara kualitatif dengan menekankan pada penalaran, yang akan membandingkan antara konsep dan pengaturan tentang hak tanggungan dengan konsep dan pengaturan tentang KIK EBA sehingga akan ditemukan order of logic dari permasalahan tersebut sebagai kesimpulan dalam penelitian ini. 


\section{Hasil Penelitian dan Pembahasan}

\section{Penerapan Konsep Trusts di Indonesia dalam Kontrak Investasi Kolektif Efek Beragun Aset (KIK-EBA)}

Definisi yang disebutkan Pasal 1 ayat (2) Peraturan Otoritas Jasa Keuangan Nomor 15/POJK.04/2014 tersebut di atas dengan tegas menjelaskan bahwa KIK-EBA adalah kontrak yang secara tertulis hanya dibuat oleh dua pihak yaitu antara manajer investasi dan bank kustodian, tetapi dalam penerapan kontrak tersebut juga mengikat pihak ketiga sebagai pemegang unit penyertaan yang dalam hal ini adalah investor. ${ }^{10}$ Konstruksi KIK-EBA yang mengikat tiga pihak sekaligus tersebut dalam sistem hukum common law dikenal dengan istilah trusts yang dalam perkembangannya juga mulai dikenal dalam sistem hukum civil law seperti di Indonesia. ${ }^{11}$

Konsep Trusts adalah konsep dimana seorang pemilik sah atas suatu benda (absolute owner) memberikan hak kebendaan atas benda tersebut kepada pihak lain yang disebut Trustee selaku legal owner untuk mengurus dan mengelola benda tersebut dengan tujuan agar benda yang dikelola itu dapat memberikan kenikmatan atau manfaat dan keuntungan kepada pihak ketiga atau yang disebut sebagai Beneficiary Owner. Keadaan ini mengakibatkan bahwa benda yang dikelola tersebut pada saat yang bersamaan dimiliki oleh dua pihak sekaligus yaitu Trustee sebagai legal owner dan pihak ketiga sebagai Beneficiary owner. ${ }^{12}$

Trusts adalah perjanjian untuk kepentingan pihak ketiga dimana trusts bukanlah suatu badan hukum sehingga tidak dapat dipailitkan, dalam konstruksi trusts, yang dapat dipailitkan adalah trusteenya dan kepailitan trustee tersebut tidak sama dengan kepailitan harta yang berada dalam trusts, dengan demikian harta tersebut bukanlah harta trustee. Kepailitan trustee hanya akan mengakibatkan harta yang berada dalam trusts beralih pemilikannya kepada trustee lainnya. ${ }^{13}$

\footnotetext{
${ }^{10}$ Agnest Elga Margareth,"Tinjauan Yuridis Terhadap Pemegang Unit Penyertaan Kontrak Investasi Kolektif Efek Beragun Aset (Asset Backed Securities) dalam Kepailitan Originator”, Skripsi, USU, Medan, 2010, hlm. 29.

${ }^{11}$ Gunawan Widjaja, Seri Aspek Hukum dalam Pasar ModalTransplantasi Trusts dalam KUH Perdata, KUHD, dan Undang-Undang Pasar Modal Indonesia, PT Rajagrafindo Persada, Jakarta,2008, hlm.177.

${ }^{12}$ Melalui Equity, seseorang yang memiliki sebuah benda untuk kepentingan pihak lain (dalam Common Law disebut sebagai absolute owner), diwajibkan untuk memenuhi kewajibanya berdasarkan Trusts (yang menjadikan orang yang memiliki benda tersebut dalam hukum disebut sebagai legal owner) kepada pihak yang memiliki hak agar kepentingan atas benda tersebut harus diberikan, Ibid., hlm.71.

${ }^{13}$ Gunawan Widjaja, "Sekuritisasi Aset... Op., Cit., hlm. 21.
} 
Dalam sistem hukum Indonesia, penerapan konsep Trusts dapat ditemukan dalam pasar modal Indonesia yang dikenal dengan istilah Kontrak Investasi Kolektif. Pasal 1 huruf a Keputusan Ketua Badan Pengawas Pasar Modal Nomor Kep28/PM/2003 mendefinisikan Kontrak Investasi Kolektif (KIK) sebagai kontrak antara Manajer Investasi dan Bank Kustodian yang mengikat pemegang Unit Penyertaan dimana Manajer Investasi diberi wewenang untuk mengelola portofolio investasi kolektif dan Bank Kustodian diberi wewenang untuk melaksanakan Penitipan Kolektif.

Persamaan konsep KIK dengan konsep trusts yang dikenal dalam sistem hukum common law adalah KIK di Indonesia memenuhi unsur-unsur trusts, yaitu sponsor bertindak sebagai settlor yang menyerahkan harta kebendaannya kepada trustee, manajer investasi dan bank kustodian kemudian bertindak sebagai trustee (dengan tugas manajer investasi melakukan pengelolaan dan pengurusan atas harta tersebut dan bank kustodian bertugas untuk melakukan penitipan kolektif atas harta itu), di sisi lain para pemegang unit penyertaan bertindak sebagai pihak yang menerima kenikmatan atau manfaat (beneficiary) atas pengelolaan yang dilakukan manajer investasi. ${ }^{14}$

Konsep trusts common law tersebut mengenal adanya pemisahan kepemilikan atas suatu benda ke dalam "ownership at law" dan "ownership in equity". Pemisahan ini mengakibatkan pada saat yang bersamaan terdapat dua pihak yang memiliki benda yang sama yaitu trustee selaku legal owner (ownership at law) dan beneficiary selaku equitable owner (ownership in equity). 15

Berbeda dengan dua kepemilikan atas benda tersebut, dalam sistem hukum civil law seperti di Indonesia, Pasal 570 Kitab Undang-Undang Hukum Perdata (KUHPerdata) merumuskan hak milik sebagai berikut:

"Hak milik adalah hak untuk menikmati kegunaan suatu kebendaan dengan leluasa dan untuk berbuat bebas terhadap kebendaan itu dengan kedaulatan sepenuhnya, asal tidak bersalahan dengan undang-undang atau peraturan umum yang ditetapkan oleh suatu kekuasaan yang berhak menetapkannya, dan tidak mengganggu hak-hak orang lain; kesemuanya itu dengan tak mengurangi kemungkinan akan pencabutan hak itu demi kepentingan umum berdasar atas ketentuan undang-undang dan dengan pembayaran ganti rugi".

${ }^{14}$ Jono, Op., Cit., hlm. 58.

${ }^{15}$ Ibid., hlm. 54-55. 
Pasal 570 KUHPerdata tersebut dengan jelas menunjukan bahwa hak milik yang diakui di Indonesia adalah hak milik dengan kedaulatan dan kewenangan sepenuhnya, tidak terbagi-bagi atau terpisah-pisah kepada pihak yang lain melainkan hanya dimiliki satu pihak yaitu pemilik hak itu.

Meskipun terjadi perbedaan konsep kepemilikan benda dalam trusts dan konsep kepemilikan dalam KUHPerdata, dalam perkembangannya ternyata konsep pemisahan kepemilikan trusts tersebut sudah digunakan dalam beberapa peraturan perundang-undangan di Indonesia, antara lain: ${ }^{16}$ pertama, ketentuan Pasal 56 ayat (1), ayat (2), dan ayat (3) Undang-Undang Nomor 8 Tahun 1995 tentang Pasar Modal (UUPM), mengatur mengenai penitipan kolektif yang memisahkan antara kepemilikan terdaftar (registered ownership) dan kepemilikan manfaat (beneficial ownership); kedua, ketentuan kedua adalah ketentuan Pasal 51 ayat (2) UUPM yang menentukan “Wali amanat mewakili kepentingan pemegang efek bersifat utang baik di dalam maupun di luar pengadilan". Penggunaan kata "wali amanat" merupakan penggantian rumusan "trustee" yang sebelumnya digunakan dalam Keputusan Menteri Keuangan No. 696/KMK.011/1985 tentang Lembaga Penunjang Pasar Modal Pasal 1 huruf (c) yang selanjutnya diubah dari istilah "trustee" menjadi "trust-agent" dalam Keputusan Menteri Keuangan No.1548/KMK.013/1990; ketiga, ketentuan ketiga adalah ketentuan dalam UUPM Pasal 1 ayat (27) yang membawa pranata trusts ke dalam sistem hukum Indonesia yaitu ketentuan mengenai reksadana kontrak investasi kolektif (RD KIK) yang melahirkan efek dalam bentuk unit penyertaan untuk diperdagangkan di bursa efek, karena dalam sistem hukum common law reksadana ini lebih dikenal dengan istilahunit trusts dan/atau investment trusts; keempat. selain ketentuan UUPM, BAPEPAM juga kemudian memperkenalkan suatu efek yang dinamakan efek beragun aset (EBA) yang diterbitkan dari perjanjian KIK-EBA, konstruksi KIK-EBA ini menyerupai RD KIK yang diterbitkan dari perjanjian KIK reksadana. ${ }^{17}$

Konsep trusts yang kemudian diterapkan dalam KIK-EBA di pasar modal Indonesia menjadikan KIK-EBA sebagai suatu persekutuan perdata yang sui generis, hal ini karena KIK lahir dari perjanjian untuk kepentingan pihak ketiga

\footnotetext{
${ }^{16}$ Gunawan Widjaja, ...Transplantasi Trusts..., Op. Cit., hlm. 6-11.

${ }^{17}$ Ibid., hlm. 13.
} 
dimana investor sebagai sekutu diam yang memperoleh kenikmatan dari trusts (KIK-EBA) sedangkan manajer investasi dan bank kustodian sebagai pengurus atau pengelola harta kebendaan trusts yang memiliki fiduciary duty kepada seluruh investor. ${ }^{18}$

\section{Penerapan Kontrak Investasi Kolektif Efek Beragun Aset Ditinjau Berdasarkan Asas Personalitas}

Bentuk KIK yang merupakan suatu perjanjian, dalam hukum yang berlaku di Indonesia diatur dalam KUHPerd yang salah satunya diatur Pasal 1313 KUHPerdata yang menentukan bahwa "suatu perjanjian adalah suatu perbuatan dimana satu orang atau lebih mengikatkan diri terhadap satu orang lain atau lebih". Perjanjian oleh para pihak yang bersepakat tersebut akan melahirkan kewajiban atau prestasi dari satu atau lebih pihak kepada satu atau lebih pihak lainya yang berhak atas kewajiban atau prestasi tersebut. ${ }^{19}$

Melengkapi mengenai perjanjian tersebut, Pasal 1315 KUHPerdata mengatur mengenai suatu asas yang merupakan salah satu asas terpenting dalam hukum perjanjian di Indonesia ${ }^{20}$ yaitu asas kepribadian atau asas personalitas (the privity of contract) yang secara umum menentukan bahwa pada umumnya tidak seorangpun dapat mengikatkan diri atas nama sendiri atau meminta ditetapkanya suatu janji melainkan untuk dirinya sendiri. ${ }^{21}$

Perkataan "mengikatkan diri" (zich verbinden) yang disebutkan Pasal 1315 KUHPerdata tersebut digunakan untuk menunjukan kepada pihak yang menyanggupi untuk melakukan sesuatu atau pihak yang memiliki kewajibankewajiban yang harus dipikul oleh pihak tersebut. Perkataan "minta ditetapkannya suatu janji" (bedingen) akan menunjukan kepada pihak yang memperoleh hak-hak atau kenikmatan-kenikmatan atas sesuatu atau dapat menuntut sesuatu. ${ }^{22}$

Ketentuan yang ditentukan Pasal 1315 KUHPerdata tersebut memiliki pengecualian sebagaimana diatur Pasal 1317 KUHPerdata yang memungkinkan

${ }^{18}$ Gunawan Widjaja, "Sekuritisasi Aset ... Op., Cit., hlm. 21.

${ }^{19}$ Kartini Muljadi dan Gunawan Widjaja, Op., Cit., hlm. 92.

${ }^{20}$ Gunawan Widjaja, Seri Aspek Hukum dalam Pasar Modal Penitipan Kolektif, PT RajaGrafindo Persada, Jakarta, 2006, hlm. 155.

${ }^{21}$ Subekti, Op. Cit., hlm. 29.

${ }^{22}$ Ibid. 
adanya perjanjian yang dibuat untuk kepentingan pihak ketiga, Pasal 1317 KUHPerdata menentukan:

"Lagipula diperbolehkan juga untuk meminta ditetapkanya suatu janji guna kepentingan seorang pihak ketiga, apabila suatu penetapan janji yang dibuat oleh seorang untuk dirinya sendiri atau suatu pemberian yang dilakukanya kepada orang lain, memuat suatu janji yang seperti itu.

Siapa yang telah memperjanjikan suatu seperti itu, tidak boleh menariknya kembali, apabila pihak ketiga tersebut telah menyatakan kehendaknya untuk mempergunakannya".

Pasal 1317 KUHPerdata di atas secara jelas menyebutkan mengenai suatu janji yang dibuat oleh seseorang untuk kepentingan seorang pihak ketiga yang dikenal dengan istilah derden beding. ${ }^{23}$ Pasal 1317 KUHPerdata tersebut hanya membuka kemungkinan untuk seseorang yang telah memenuhi persyaratan yang diberikan dapat menikmati keuntungan suatu kebendaan atau hal tertentu, berdasarkan pada perjanjian yang dibuat diantara dua pihak tertentu.

Perjanjian untuk pihak ketiga yang diatur Pasal 1317 KUHPerdata menunjukan bahwa dalam pelaksanaan perjanjian untuk pihak ketiga terdapat konstruksi hukum yang hampir sama dengan konsep trusts yaitu adanya dua pihak yang berkedudukan sebagai pengelola berdasarkan perjanjian yang mereka buat dan adanya pihak ketiga yang berkedudukan sebagai penerima manfaat atau kenikmatan dari perjanjian yang dibuat oleh para pembuat perjanjian untuk pihak ketiga tersebut. ${ }^{24}$

Meskipun konstruksi hukum pemberian janji untuk pihak ketiga menyerupai konsep trusts, konsep trusts dalam KIK-EBA di Indonesia sesungguhnya memiliki konsep yang tidak sama dengan perjanjian untuk pihak ketiga (derden beding) yang diatur Pasal 1317 KUHPerdata.

Perbedaan itu terjadi karena dalam perjanjian derden beding seseorang atau suatu pihak boleh saja mengadakan perjanjian dengan pihak lain untuk kemanfaatan pihak ketiga tetapi tidak untuk membebaninya, sehingga hak yang diperjanjikan untuk pihak ketiga ini akan menjadi beban atau kewajiban bagi pihak lawan dalam perjanjian tanpa adanya surat kuasa dari pihak ketiga tersebut. ${ }^{25}$

\footnotetext{
${ }^{23}$ Ibid., hlm. 30.

${ }^{24}$ Gunawan Widjaja, ...Penitipan Kolektif...Op. Cit., hlm. 161.

${ }^{25}$ Subekti, Op., Cit., hlm. 30.
} 
Perkataan "... untuk meminta ditetapkanya suatu janji guna kepentingan seorang pihak ketiga..." yang disebutkan Pasal 1317KUHPerdata tersebut dengan jelas menunjukan bahwa perjanjian untuk pihak ketiga (derden beding) adalah perjanjian yang hanya akan memberikan kenikmatan-kenikmatan kepada pihak ketiga tanpa adanya suatu kewajiban yang dituntut pemenuhannya kepada pihak ketiga, karena janji untuk pihak ketiga tersebut merupakan suatu penawaran (offerte) yang dilakukan oleh pihak yang meminta diperjanjikannya hak-hak (stipulator) kepada pihak ketiga tersebut. ${ }^{26} \mathrm{Hal}$ ini berarti bahwa dalam konsep derden beding yang dikenal di Indonesia, pihak ketiga hanya berkedudukan sebagai penerima manfaat dari perjanjian yang dibuat oleh para pihak tanpa ada kewajiban apapun yang dibebankan kepada pihak ketiga.

KIK-EBA yang diterapkan di Indonesia sebagai perjanjian yang sui generis menjadi sangat unik karena dalam KIK-EBA selain pihak ketiga diberi suatu hak, pihak ketiga itu juga dibebani suatu kewajiban yaitu untuk membeli unit penyertaan yang dikeluarkan oleh manajer investasi. Perbedaan yang terjadi antara penerapan KIK-EBA dengan perjanjian untuk pihak ketiga yang diatur Pasal 1317 KUHPerdata ini mengakibatkan KIK-EBA bukanlah menjadi salah satu pengecualian atas asas personalitas yang diatur Pasal 1340 KUHPerdata melainkan bentuk perjanjian baru yang konstruksi hukumnya tidak dikenal dalam sistem hukum Indonesia.

Selain tidak memenuhi asas personalitas, penerapan KIK-EBA juga tidak memenuhi syarat khusus suatu perjanjian yaitu syarat formal yang ditentukan oleh peraturan perundang-undangan Indonesia. Pasal 1337 KUHPerdata yang menentukan adanya syarat khusus bahwa setiap perjanjian yang memiliki ketentuan berdasarkan peraturan perundang-undangan yang berlaku merupakan perjanjian formil yang harus dipenuhi semua formalitasnya. Oleh karena itu, perjanjian KIK-EBA terikat dengan ketentuan Pasal 16 ayat (2) UUHT yang mensyaratkan untuk melakukan pendaftaran terhadap peralihan hak tanggungan dalam KIK-EBA.

Tidak terpenuhinya syarat khusus yang menjadi formalitas suatu perjanjian yang ditentukan oleh peraturan perundang-undangan yang berlaku di Indonesia tersebut mengakibatkan KIK-EBA menjadi batal demi hukum. ${ }^{27}$

${ }^{26}$ Ibid.

${ }^{27}$ Ibid., hlm. 25. 
Status Kepemilikan Hak Tanggungan atas Kredit Pemilikan Rumah yang Piutangnya Dialihkan dengan Cara Sekuritisasi Aset

\section{Kepemilikan Hak Tanggungan atas Tanah Sebelum dilakukannya Sekuritisasi}

Pasal 9 UUHT menentukan bahwa "Pemegang hak tanggungan adalah orang perseorangan atau badan hukum yang berkedudukan sebagai pihak yang berpiutang". Pasal 9 UUHT ini dengan tegas menyebutkan bahwa pemegang atau pemilik hak tanggungan adalah pihak yang berpiutang atau yang lebih dikenal dengan istilah kreditor dalam perjanjian utang-piutang. ${ }^{28}$ Kreditor ini yang kemudian dalam sekuritisasi aset akan menjadi kreditor asal karena menjual piutangnya kepada kreditor yang baru. ${ }^{29}$

Peraturan Presiden Nomor 19 Tahun 2005 tentang Pembiayaan Sekunder Perumahan Pasal 1 ayat (7) memberikan pengertian tentang istilah kreditor asal (originator atau mortgage lenders) yaitu "Kreditor asal adalah setiap bank atau lembaga keuangan yang mempunyai aset keuangan".

Aset keuangan dalam hal ini merupakan piutang yang diperoleh dari penerbitan Kredit Pemilikan Rumah (KPR) termasuk hak agunan yang melekat pada piutang tersebut ${ }^{30}$ yang akan dijual kepada lembaga pembiayaan sekunder perumahan untuk memperoleh dana yang dipergunakan dalam membeli fasilitas KPR baru yang disediakan terhadap calon debitor lainya. ${ }^{31}$

Peraturan Presiden Nomor 19 Tahun 2005 di atas menunjukan bahwa pihak yang bertindak sebagai originator atau sebagai kreditor asal yang memiliki piutang beserta agunannya yaitu hak tanggungan adalah bank atau lembaga keuangan lainya yang akan menjual piutang tersebut kepada lembaga pembiayaan sekunder perumahan, dengan demikian, sebelum dilakukannya sekuritisasi piutang, status kepemilikan hak tanggungan adalah milik bank atau lembaga keuangan lainya yang memiliki piutang dalam bentuk KPR. ${ }^{32}$

${ }^{28}$ Pasal 1 ayat (2) UUHT.

${ }^{29}$ Gunawan Widjaja, "Sekuritisasi Aset ...Op. Cit., hlm. 20.

${ }^{30}$ Pasal 1 ayat (2) Peraturan Presiden Nomor 19 Tahun 2005 tentang Pembiayaan Sekunder Perumahan.

${ }^{31}$ Syafaruddin Harahap, "Tinjauan Yuridis Kontrak Investasi Kolektif Efek Beragun Aset Di Bank BTN", Tesis, Undip, Semarang, 2010, hlm. 98.

32Pasal 9 UUHT. 


\section{Kepemilikan Hak Tanggungan atas Tanah dalam Kontrak Investasi Kolektif Efek Beragun Aset (KIK-EBA).}

Diterapkannya konsep trusts dalam reksadana yang berbentuk KIK yang kemudian juga diterapkan dalam KIK-EBA karena memiliki mekanisme yang sama, berdasarkan sistem hukum yang berlaku di Indonesia akan melahirkan tiga hubungan hukum diantara pihak-pihaknya, yaitu hubungan jual beli piutang antara kreditor asal (originator) dan manajer investasi. Hubungan dalam KIK-EBA antara manajer investasi dan bank kustodian, kemudian hubungan antara manajer investasi dan bank kustodian terikat dalam KIK-EBA dengan investor yang membeli unit penyertaan KIK-EBA. ${ }^{33}$

Lahirnya tiga hubungan hukum tersebut akan menimbulkan akibat hukum yang berbeda-beda diantara para pihak, yaitu: a. hubungan jual beli piutang yang dilakukan oleh manajer investasi dan kreditor asal (originator). ${ }^{34}$ Piutang yang dimiliki oleh kreditor asal atau originator akan dialihkan kepada kreditor baru dengan cara jual beli, kreditor baru dalam KIK-EBA dilakukan oleh manajer investasi yang bertindak sebagai pihak pembeli tagihan (piutang) yang dijual originator dan kemudian mengeluarkan sertifikat utang 35 atau unit penyertaan untuk dijual kepada investor berdasarkan kontrak. ${ }^{36}$

Hubungan ini akan mengakibatkan terjadinya peralihan kepemilikan piutang dari kreditor asal kepada manajer investasi karena transaksi jual beli dilakukan dengan mekanisme jual putus sehingga piutang tidak akan kembali kepada kreditor asal; b. hubungan antara manajer investasi dan bank kustodian dalam KIK-EBA. ${ }^{37}$ Hubungan hukum ini akan melahirkan akibat hukum bagi manajer investasi dan bank kustodian dimana manajer investasi diberi kewenangan untuk mengelola portofolio investasi kolektif sedangkan bank kustodian diberi

${ }^{33}$ Baca Peraturan BAPEPAM dan LK No. IX.K.1 tentang Pedoman Kontrak Investasi Kolektif Efek Beragun Aset (Asset Backed Securities) Pasal 1 sampai dengan Pasal 5.

${ }^{34}$ Gunawan Widjaja, "Sekuritisasi Aset ...Op., Cit., hlm. 20.

${ }^{35}$ Sertifikat utang atau unit penyertaan tersebut dapat timbul dari adanya sekuritisasi aset tagihan dari perusahaan tertentu atau piutang perusahaan yang dirubah menjadi aset yang lebih likuid melalui penciptaan surat berharga, baca Agnest Elga Margareth, Op. Cit., hlm. 19.

${ }^{36}$ Tim Studi Perdagangan Efek Beragun Aset, Studi TentangPerdaganganEfek Beragun Aset, Departemen Keuangan Republik Indonesia, Badan Pengawas Pasar Modal Proyek Peningkatan Efisiensi Pasar Modal, 2003, hlm. 15.

${ }^{37}$ Pasal 1 huruf (a) Peraturan BAPEPAM dan LK No. IX.K.1 tentang Pedoman Kontrak Investasi Kolektif Efek Beragun Aset (Asset Backed Securities). 
wewenang untuk melaksanakan penitipan kolektif. Kewenangan tersebut kemudian akan digunakan untuk mengelola piutang yang dibeli dari kreditor asal dengan menyekuritisasi piutang tersebut menjadi unit penyertaan dan menawarkannya untuk dibeli oleh para investor; c. hubungan hukum antara manajer investasi dan bank kustodian yang telah terikat dalam KIK-EBA dengan para investor. ${ }^{38}$

Unit penyertaan yang dijual oleh manajer investasi kepada investor tersebut adalah EBA atau unit penyertaan KIK yang portofolionya terdiri dari aset keuangan. Aset keuangan ini dapat berupa tagihan yang timbul dari surat berharga komersial, sewa guna usaha, perjanjian jual-beli bersyarat, perjanjian pinjaman cicilan, tagihan kartu kredit, pemberian kredit termasuk kredit pemilikan rumah atau apartemen, efek yang bersifat utang yang dijamin oleh pemerintah, sarana peningkatan kredit, serta aset keuangan lain yang berkaitan dengan aset keuangan tersebut. 39

Dua hubungan hukum dari tiga hubungan hukum yang terjadi di atas adalah hubungan hukum yang terjadi karena perjanjian jual beli, yaitu perjanjian jual beli piutang antara manajer investasi dan kreditor asal serta perjanjian jual beli unit penyertaan antara manajer investasi dengan para investor.

Perjanjian jual beli yang dilakukan oleh para pihak dalam KIK tersebut akan mengalihkan kepemilikan piutang kepada pihak-pihak yang membeli piutang, yaitu peralihan piutang dari kreditor asal kepada manajer investasi dan kemudian peralihan piutang dalam bentuk unit penyertaan dari manajer investasi kepada para investor. Terjadinya peralihan piutang tersebut dikarenakan jual beli piutang dilakukan secara cessie sehingga piutang benar-benar beralih kepada pihak yang membelinya yang secara berurutan beralih kepada manajer investasi dan kemudian akan beralih lagi kepada para investor. ${ }^{40}$ Sesuai dengan sifat jaminan di Indonesia yang accesior, peralihan-peralihan piutang tersebut juga disertai dengan peralihan hak tanggungan yang melekat kepadanya. ${ }^{41}$

${ }^{38}$ Ibid.

${ }^{39}$ Munir Fuady, Pasar Modal Modern (Tinjanan Hukum), Buku Kedua, cetakan kedua, PT Citra Aditya Bakti, Bandung, 2003, hlm. 39-40.

${ }^{40}$ Ibid., hlm. 54.

${ }^{41}$ Boedi Harsono, Hukum Agraria Indonesia Sejarah Pembentukan Undang-Undang Pokok Agraria, Isi dan Pelaksanaannya Jilid 1 Hukum Tanah Nasional, Cetakan Ke-11,Djambatan,Jakarta, 2007, hlm. 420. 
Terjadinya peralihan piutang dalam bentuk unit penyertaan yang dibeli oleh investor tersebut, sesuai dengan Pasal 16 ayat (1) UUHT dan sifat hukum jaminan yang accesoir maka hak tanggungan juga ikut beralih menjadi milik investor sebagai pemilik unit penyertaan. Dengan demikian, secara teori pemilik hak tanggungan dalam KIK-EBA adalah para investor pemegang unit penyertaan yang berasal dari KIK-EBA.

Kepemilikan investor terhadap hak tanggungan dalam KIK-EBA tersebut di atas adalah kepemilikan yang hanya berdasarkan teori saja, karena jika dikaji berdasarkan peraturan perundang-undangan yang berlaku terutama UUHT, maka pemilik hak tanggungan yang melekat pada piutang yang diperjual-belikan dalam KIK-EBA bukanlah para investor. Hal tersebut dapat dijabarkan sebagai berikut: pertama, peralihan hak tanggungan tidak disertai dengan pendaftaran sesuai dengan Pasal 16 ayat (2) UUHT. Tidak didaftarkanya peralihan hak tanggungan ke kantor pertanahan akan berakibat tidak adanya perubahan catatan kepemilikan hak tanggungan yang tercatat dalam buku tanah hak tanggungan yang bersangkutan dan pada buku-tanah objek yang dibebani hak tanggungan, termasuk pada sertifikat hak tanggungan dan sertifikat objeknya, sehingga hak tanggungan akan tetap dimiliki oleh pihak yang namanya tercantum dalam sertifikat hak tanggungan tersebut. ${ }^{2}$ Kedua, peralihan piutang yang dilakukan secara cessie tidak dilakukan dengan peralihan yang sempurna. Ketidaksesuaian antara kepemilikan piutang dan hak tanggungan tersebut di atas juga akan berakibat kepada proses peralihan piutang yang dilakukan secara cessie. Tidak beralihnya hak tanggungan kepada investor mengikuti piutang yang dijual juga akan berakibat perjanjian jual-beli yang dilakukan kreditor asal dan kreditor baru tidak memenuhi sifat accesoir hukum jaminan yang ditentukan Pasal 16 UUHT. Pelanggaran terhadap Pasal 16 UUHT tersebut akan menyebabkan tidak terpenuhinya syarat formal atau syarat khusus perjanjian yang ditentukan oleh

${ }^{42}$ Sesuai dengan Pasal 1 ayat (1) UUHT yang dengan jelas menyatakan bahwa perlindungan hanya akan diberikan kepada kreditor pemegang Hak Tanggungan yaitu orang yang namanya tercatat dalam Sertifikat Hak Tanggungan dan sesuai dengan salah satu asas hak tanggungan yang memberikan kedudukan yang diutamakan (preferent) kepada kreditornya 
undang-undang yang akan mengakibatkan perjanjian jual beli piutang tersebut menjadi batal demi hukum. ${ }^{43}$

Batalnya perjanjian jual-beli yang merupakan perjanjian obligatoir terhadap cessie secara otomatis juga akan membatalkan cessie sebagai accesoir perjanjian jualbeli tersebut, sehingga piutang tidak berpindah ke tangan cessionaries (investor) dan tetap berada di tangan kreditor asal. Berdasarkan hal-hal tersebut di atas, dapat disimpulkan bahwa hak tanggungan dalam kontruksi hukum KIK-EBA tidak dapat dimiliki oleh manajer investasi maupun para investor melainkan tetap berada di tangan kreditor asal.

\section{Penutup}

Berdasarkan penelitian tersebut di atas dapat disimpulkan: pertama, akibat hukum penerapan KIK-EBA jika ditinjau berdasarkan asas personalitas yang dianut Indonesia adalah KIK-EBA yang diterapkan tersebut tidak memenuhi asas personalitas bahkan tidak memenuhi syarat khusus yang menjadi formalitas suatu perjanjian yang ditentukan oleh peraturan perundang-undangan yang berlaku di Indonesia yaitu Pasal 16 ayat (2) UUHT yang mensyaratkan adanya pendaftaran terhadap peralihan hak tanggungan yang terjadi termasuk peralihan hak tanggungan dalam KIK-EBA yang mengakibatkan KIK-EBA menjadi batal demi hukum. Kedua, status kepemilikan hak tanggungan atas kredit pemilikan rumah yang piutangnya dialihkan dengan cara sekuritisasi aset tersebut adalah sebagai berikut: a) sebelum dilakukannya sekuritisasi piutang, status kepemilikan hak tanggungan adalah milik bank atau lembaga keuangan lainya yang memiliki piutang dalam bentuk KPR; b) sekuritisasi piutang yang mendasarkan pada konsep KIK-EBA yang menyerupai trusts, hak tanggungan tidak dapat dimiliki oleh manajer investasi maupun para investor karena konsep trusts tersebut memiliki banyak benturan dengan sistem hukum yang berlaku di Indonesia terutama

${ }^{43}$ Menurut Subekti, selain karena tidak terpenuhinya syarat sahnya perjanjian yang ditentukan Pasal 1320 KUHPerdata, suatu perjanjian juga akan menjadi batal jika tidak memenuhi syarat khusus perjanjian atau syarat yang menjadi formalitas suatu perjanjian yang ditentukan oleh Undang-Undang, tidak terpenuhinya syarat khusus ini akan berakibat perjanjian tersebut batal demi hukum, baca Subekti, Hukum Perjanjian, Ctk. Kesembilanbelas, PT. Intermasa,Jakarta, 2002, hlm. 25. Bandingkan dengan kebatalan non-existent dalam Mulyoto, Perjanjian; Tehnik, Cara Membuat, dan Hukum Perjanjian yang Harus Dikuasai, Cakrawala Media, Yogyakarta, 2012, hlm. 45. 
dengan hukum jaminan yang salah satunya diatur UUHT, sehingga kepemilikan hak tanggungan tetap berada di tangan kreditor asal.

Berdasarkan hasil penelitian di atas, disarankan bahwa: pertama, harus dilakukan pengaturan ulang secara menyeluruh mengenai KIK-EBA agar sesuai dengan semua peraturan perundang-undangan yang berlaku di Indonesia terutama asas personalitas dan Pasal 16 ayat (2) UUHT. Kedua, perlindungan hukum yang lebih jelas dan dengan prosedur yang lebih baik sangat dibutuhkan untuk tetap menjaga KIK-EBA dapat dilaksanakan secara produktif di Indonesia, mengingat KIK-EBA ini merupakan salah satu mekanisme investasi yang sangat penting dalam perkembangan perekonomian Indonesia. Ketiga, perlu dibuat undang-undang tersendiri yang mengatur secara khusus pemberlakukan KIK-EBA di Indonesia agar dapat memberikan kepastian dan perlindungan hukum kepada semua pihak yang terkait dengan KIK-EBA. Sehingga diharapkan dengan adanya undang-undang tentang kontrak investasi kolektif efek beragun aset akan meningkatkan kepercayaan dan minat para investor asing untuk menginvestasikan dana yang mereka miliki ke Indonesia.

\section{Daftar Pustaka}

Fuady, Munir, Pasar Modal Modern (Tinjauan Hukum), Buku Kedua, Cetakan Kedua, PT Citra Aditya Bakti, Bandung, 2003.

Harsono, Boedi, Hukum Agraria Indonesia Sejarah Pembentukan Undang-Undang Pokok Agraria, Isi dan Pelaksanaannya Jilid 1 Hukum Tanah Nasional, Cetakan Ke-11, Djambatan, Jakarta, 2007.

Muljadi, Kartini, dan Gunawan Widjaja, Perikatan Yang Lahir dari Perjanjian, PT Rajagrafindo Persada, Jakarta, 2003.

Mulyoto, Perjanjian: Tehnik, Cara Membuat, dan Hukum Perjanjian yang Harus Dikuasai, Cakrawala Media, Yogyakarta, 2012.

Satrio, J. Hukum Perjanjian (Perjanjian Pada Umumnya), Cetakan Pertama, PT. Citra Aditya Bakti, Jakarta,1992.

Subekti, Hukum Perjanjian, Cetakan Kesembilanbelas, PT. Intermasa, Jakarta, 2002.

Widjaja, Gunawan, Seri Aspek Hukum dalam Pasar Modal Penitipan Kolektif, PT RajaGrafindo Persada, Jakarta, 2006. 
Seri Aspek Hukum dalam Pasar Modal Transplantasi Trusts dalam KUH Perdata, KUHD, dan Undang-Undang Pasar Modal Indonesia, PT RajaGrafindo Persada, Jakarta, 2008.

Harahap, Syafaruddin, “Tinjauan Yuridis Kontrak Investasi Kolektif Efek Beragun Aset Di Bank BTN” Tesis, Undip, Semarang, 2010.

Jono, “Tinjauan Yuridis Reksa Dana yang Berbentuk Kontrak Investasi Kolektif Sebagai Bentuk Trusts" Jurnal Hukum Bisnis, Volume 25- No.01, 2006.

Margareth, Agnest Elga, “Tinjauan Yuridis Terhadap Pemegang Unit Penyertaan Kontrak Investasi Kolektif Efek Beragun Aset (Asset Backed Securities) dalam Kepailitan Originator" Skripsi, Universitas Sumatera Utara, Medan, 2010.

Tim Studi Perdagangan Efek Beragun Aset, Departemen Keuangan Republik Indonesia, Badan Pengawas Pasar Modal Proyek Peningkatan Efisiensi Pasar Modal, 2003, Studi Tentang Perdagangan Efek Beragun Aset.

Widjaja, Gunawan, "Sekuritisasi Aset dalam Kegiatan Pasar Modal dan Dampak Kasus Subprime Mortgage di Amerika Serikat Terhadap Pasar Sekuritas Global" Jurnal Hukum Bisnis, Volume 27-No.03, 2008.

Subekti dan Tjitrosudibio, Kitab Undang-Undang Hukum Perdata, Cetakan Ke-32 PT. Pradnya Paramita, Jakarta, 2002.

Undang-Undang Nomor 5 Tahun 1960 tentang Peraturan Dasar Pokok-Pokok Agraria.

Undang-Undang Nomor 4 Tahun 1996 tentang Hak Tanggungan atas Tanah Beserta Benda-Benda yang Berkaitan dengan Tanah.

Undang-Undang Nomor 21 Tahun 2011 tentang Otoritas Jasa Keuangan.

Peraturan Presiden Nomor 19 Tahun 2005 tentang Pembiayaan Sekunder Perumahan.

Peraturan BAPEPAM dan LK No. IX.K.1 tentang Pedoman Kontrak Investasi Kolektif Efek Beragun Aset (Asset Backed Securities), Keputusan Ketua Badan Pengawas Pasar Modal dan Lembaga Keuangan Nomor Kep493/BL/2008. 